\title{
Cytomegalovirus infection in the neonate and its prevention
}

\author{
H. STERN \\ M.B., Ch.B., Ph.D., F.R.C.Path. \\ Department of Virology, St George's Hospital Medical School, London SW1
}

\begin{abstract}
Summary
About $0.5 \%$ of infants are infected in utero with cytomegalovirus (CMV). As many as $20 \%$ become mentally retarded and a further substantial proportion suffer lesser degrees of brain damage. The need for a vaccine is greater than in the case of rubella. A live, tissue culture-adapted strain of CMV has been shown to produce neutralizing antibody in volunteers without significant side effects or detectable virus excretion. The problems of developing such a vaccine for use in man, namely, attenuation, antigenic differences among virus strains, reactivation of latent infection and oncogenicity, are briefly discussed.
\end{abstract}

Cytomegalovirus (CMV) is a commoner cause of fetal damage than rubella virus and also probably more serious, since it is the brain that is predominantly affected. About $40 \%$ of women of childbearing age in the United Kingdom are without CMV antibodies (compared with $15-20 \%$ in the case of rubella) and are therefore susceptible to infection, and $2-3 \%$ of them experience primary infection at some time during the course of pregnancy (Stern and Tucker, 1973). The risk of infection for the fetus is of the order of $50 \%$ which means that about $0.5 \%$ of all infants are born congenitally infected and excreting the virus in the throat and urine. This has been confirmed by direct studies on newborn infants. Among 4259 unselected infants in London, from whom a urine specimen was collected on the day of birth, there were sixteen excreting CMV (0.4\%) (Stern, unpublished data). One died shortly after birth, two had minor, transient illnesses and thirteen were apparently asymptomatic. Nevertheless, over a period of 3-6 months' observation, three of the fifteen survivors were recognized to be severely mentally retarded $(20 \%)$. Proportionally, this means the birth of about 500 retarded infants in the U.K. every year, more than double the number of cases of congenital rubella in nonepidemic years. This is not, however, the full picture since it is now known that congenital infection with CMV can cause lesser degrees of brain damage, leading to such abnormalities as sensori-neural deafness and perhaps also reduced intelligence, which may not become obvious until much later, often not until the child starts school (Reynolds et al., 1974; Hanshaw, 1976). It is likely, therefore, that CMV has a still wider role as a possible cause of learning difficulties, speech defects, behaviour problems and other manifestations of limited brain damage that may double or triple the figure of 500 damaged infants.

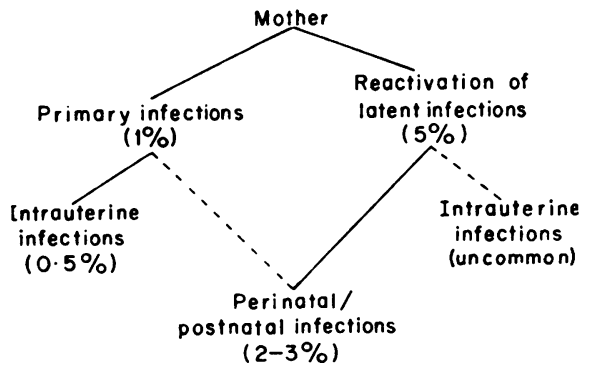

FIG. 1. Sources of intrauterine, perinatal and early postnatal cytomegalovirus infection.

The viraemia of primary infection in the pregnant woman is certainly the principal source of infection for the fetus in utero, but there are other possible mechanisms of infection (Fig. 1). Following primary infection in pregnancy, the mother often continues to excrete virus, in the throat and urine, on the cervix and in the milk, for long periods after term (Medearis, 1964). Some of the infants who manage to escape intrauterine infection may, therefore, become infected at the time of birth, as they pass through the cervix or, subsequently, from the mother's mouth or her milk when breast-feeding. However, a more important source of such perinatal and early postnatal infection is reactivation of latent infection. As with other herpes viruses, infection with CMV is followed by persistence of the virus in the body, in a latent form, probably for the rest of life. This latent infection can reactivate in pregnancy, probably as a result of the physiological immunosuppression that develops during pregnancy (Montgomery, Youngblood and Medearis, 1972). About $60 \%$ of women of child-bearing age in the U.K. have CMV antibodies and are latently infected. Probably fewer than $5 \%$ of 
them reactivate during pregnancy, although in other countries, such as Japan, the reactivation rate is almost 30\% (Numazaki et al., 1970). This difference may be related to the age of primary infection; in most European populations CMV infection occurs predominantly in adolescence and early adult life, whereas in more crowded countries, such as Japan, most infections take place in early childhood. Possibly, this early infection before the immunity mechanisms are fully mature, leads to a more unstable latent state. At any rate, reactivation can also be followed by excretion of virus for weeks or months after term, and about $50 \%$ of the infants born to women who reactivate are infected from the cervix at birth, or later from the mother's mouth or milk (Reynolds et al., 1973). The infected infants do not begin to excrete virus until 4-6 weeks later, compared with congenitally infected babies who already excrete virus on the day of birth. These relatively late infections occasionally cause respiratory illness, of greater or lesser severity, or mild disturbances of liver function, but mostly they are asymptomatic and, as far as is known, there is no damage to the brain such as occurs with intrauterine infection (Levinsohn et al., 1969).

There are several reports in the literature of intrauterine infection following reactivation of latent infection (Stagno et al., 1973; Evans, McCollum and Valdimarsson, 1975) However, this is uncommon; in the great majority of cases, pre-existing circulating antibody effectively prevents passage of free virus across the placenta (Montgomery et al., 1972; Reynolds et al., 1973; Stagno et al., 1975). For example, despite the very high frequency of reactivation in pregnant women in Japan and other Far Eastern countries the incidence of congenital infection is no higher than elsewhere (Alexander, 1967; Numazaki et al., 1970; Olson et al., 1970).

There is a further important source of perinatal infection in the form of exchange transfusions for blood group incompatibility, since about $5 \%$ of blood donors carry CMV in their peripheral leucocytes as part of their latent infection. However, these transfusion infections are also usually asymptomatic and apparently without sequelae (Luthardt et al., 1971; Yeager, 1974).

The frequency and severity of congenital CMV infection make prevention an important matter. To detect the primary infections when they occur in pregnancy is much more difficult than in the case of rubella. This is because CMV infections in adults are almost invariably subclinical; there is no clinical warning sign, such as the rash in rubella. Diagnosis is therefore entirely dependent on the laboratory. Since most women do not come for confirmation of pregnancy until the second or third month or later, screening for CMV infection would require an initial test for CMV-specific IgM antibody at the first antenatal attendance, to detect any infection that might already have occurred during the early months, and this would have to be followed, in those without any CMV antibody at all, by further tests at intervals up to, say, the twentieth week; unlike rubella, CMV can severely damage the fetus also during the second trimester (Monif et al., 1972; Stern and Tucker, 1973). It is doubtful whether such a monitoring regime could be established for all women, on a national scale, and particularly for young unmarried girls who become pregnant and who seem to provide an unusually high proportion of all congenitally infected infants. The obvious answer is a vaccine that would be administered, perhaps at the same time as rubella vaccine, to girls aged 11-14 years. Only a live vaccine would be expected to produce sufficiently long-term immunity to persist throughout the subsequent child-bearing years. However, there are unusual problems involved in developing for the first time a live herpes virus vaccine for use in man.

\section{Vaccination}

There are four main problems attaching to the use of a live CMV vaccine:

\section{(1) Attenuation}

Natural infection with CMV rarely seems to cause illness in healthy individuals. Nevertheless, in the case of both CMV vaccines at present under investigation, standard practice was followed and they were prepared by long-term, serial passage of the respective strains of virus in human diploid fibroblast tissue cultures (Elek and Stern, 1974; Just et al., 1975). Because CMV is highly speciesspecific, initial tests of the vaccines could be done only in volunteers. Subcutaneous injection has produced antibody in almost every case and, even with high doses, there have been no significant local or general reactions. An important advantage of the parenteral route of inoculation is the absence of excretion of the vaccine virus, thus avoiding the immediate problems of cross-spread to contacts, particularly pregnant women.

\section{(2) Antigenic differences among human strains of CMV}

Human strains of the virus do show minor differences in cross-neutralization tests; these do not seem to be related to the source of the virus, either the part of the body from which it was isolated or the illness. However, with both hyperimmune animal sera and convalescent human sera extensive crossreactions are obtained among these strains(Andersen, 1970, 1971, 1972; Graham et al., 1971; Haines, von Essen and Benyesh-Melnick, 1971), and vaccinated volunteers produced good levels of antibody 
against all three prototype strains of CMV (Elek and Stern, 1974). There is also relevant information from patients undergoing open-heart surgery. These operations require massive transfusions of blood from multiple donors, which means a high likelihood of intravenous inoculation of CMV-infected leucocytes. Yet, illness, the post-perfusion syndrome, is seen almost exclusively in patients who were without pre-existing antibody before the operation (Embil et al., 1968; Henle et al., 1970; Stevens et al., 1970; Perham et al., 1971). Subclinical infection, too, is significantly more common in such patients and rarely occurs in those with high levels of pre-existing antibody (Paloheimo et al., 1968; Henle et al., 1970; Caul et al., 1971; Med. Res. Coun. Study, 1974); in patients with low levels of antibody, any increase in titre after operation is, in fact, probably due to reactivation of latent infection rather than new infection (Olding, Jensen and Oldstone, 1975). This argues against significant antigenic differences among strains and for protection by circulating antibody against exogenous re-infection. It therefore seems unlikely that more than a single strain of CMV will be needed to provide an effective vaccine.

\section{(3) Reactivation of latent infection}

There is no reason to doubt that vaccine strains of CMV will establish long-term latent infection as readily as wild strains. However, as discussed above, primary infection of immunologically mature subjects, at 11-14 years of age, would not be expected to lead to any unusual incidence of reactivation. Even should reactivation occur in subsequent pregnancies, pre-existing circulating antibody should provide effective protection against placental passage of any virus liberated into the tissues.

A high proportion of those patients given a kidney transplant who are without CMV antitodies beforehand suffer primary infection subsequently, and this is often associated with illness which can be serious and fatal (Armstrong et al., 1971; Spencer, 1974; Ho et al., 1975). Vaccination of these patients before kidney transfer may help to prevent or modify these complications. At the same time, such vaccinations, which can be justified clinically, would provide invaluable data on both the attenuation of the vaccine virus and its propensity to latency and reactivation.

\section{(4) Oncogenicity}

This is probably the most difficult problem. Some herpes viruses are undoubtedly oncogenic, e.g. Marek's disease virus of the domestic fowl and the virus causing renal adenocarcinoma in the leopard frog. In man, Epstein-Barr virus is closely involved with African Burkitt's lymphoma and nasopharyngeal carcinoma, and there is much, admittedly indirect, evidence linking herpes simplex virus type 2 with cancer of the cervix. On the other hand, many live herpes viruses, including infectious bovine rhinotracheitis virus, equine rhinopneumonitis virus, pseudo-rabies virus of pigs and several other chicken viruses, have been used for many years to immunize these domestic animals, without any evidence of oncogenic activity. CMV, itself, does have demonstrable oncogenic activity in vitro, being capable of transforming both hamster and human fibroblast tissue culture cells (Albrecht and Rapp, 1973; Geder et al., 1976). However, there appear to be strain differences in this respect. Moreover, in the case of Marek's disease virus and herpes virus saimiri, which causes malignant lymphoproliferative disease in its unnatural host, the squirrel monkey, adaptation to tissue culture can lead to loss of oncogenic activity, and, when used as live vaccines, the adapted strains offer protection against the oncogenic effects of superinfection with wild strains (Churchill, Payne and Chubb, 1969; Schaffer, Falk and Deinhardt, 1975). This is encouraging for the use of a tissue cultureadapted strain of CMV for vaccination in man.

Obviously much more work is needed but no vaccine in current use today can be guaranteed free of possible, rare complications. Indeed, recent work has indicated that even common RNA viruses, such as measles, respiratory syncytial and influenza viruses, may establish latent infection in host cells by form ing, perhaps with the help of endogenous oncornavirus reverse transcriptase, DNA proviral replicas of themselves (Zhdanov, 1975; Simpson and Iinuma, 1975); this obviously also carries reactivation and oncogenic implications. Doubts have also been raised about the suitability of cultured cells as models for in vivo transformation and cancer (Shields, 1976). There will be no quick answer to these problems, and one is compelled to weigh the real advantages of preventing a common and tragic disease against what are still very largely theoretical, and probably rare, complications.

\section{References}

AlbRecht, T. \& RAPP, F. (1973) Malignant transformation of hamster embryo fibroblasts following exposure to ultraviolet-irradiated human cytomegalovirus. Virology, 55, 53.

Alexander, E.E. (1967) Maternal and neonatal infection with cytomegalovirus in Taiwan. Pediatric Research, 1, 210.

ANDERSON, H.K. (1970) Complement-fixing and neutralising antibodies in cytomegalovirus infection as measured against homologous and heterologous antigen. Acta pathologica et microbiologica scandinavica, 78, 504.

ANDERSEN, H.K. (1971) Serologic differentiation of human cytomegalovirus strains using rabbit hyperimmune sera. Archiv für die gesamte Virusforschung, 33, 187.

ANDERSEN, H.K. (1972) Studies of human cytomegalovirus strain variations by kinetic neutralisation tests. Archiv für die gesamte Virusforschung, 38, 297. 
Armstrong, D., Balukrishnan, S.L., Steger, L., Yu, B. \& Stenzel, K.H. (1971) Cytomegalovirus infections with viremia following renal transplantation. Archives of Internal Medicine, 127, 111.

Caul, E.O., Clarke, S.K.R., Mott, M.G., Perham, T.G.M. \& Wilson, R.S.E. (1971) Cytomegalovirus infections after open heart surgery. Lancet, $i, 777$.

Churchill, A.E., PAyne, L.N. \& ChubB, R.C. (1969) Immunisation against Marek's disease using a live attenuated virus. Nature. London, 221, 744.

ElEK, S.D. \& STERN, H. (1974) Development of a vaccine against mental retardation caused by cytomegalovirus infection in utero. Lancet, $\mathbf{i}, 1$.

Embil, J.A., Folkins, D.F., Haldane, E.V. \& Van Rooyen, C.E. (1968) Cytomegalovirus infection following extracorporeal circulation in children. Lancet, ii, 1151.

Evans, T.J., McCollum, J.P.K. \& Valdimarsson, H. (1975) Congenital cytomegalovirus infection after maternal renal transplantation. Lancet, i, 1359.

Geder, L., Lausch, R., O'Neill, F. \& RaPP, F. (1976) Oncogenic transformation of human embryo lung cells by human cytomegalovirus. Science, 192, 1134.

Graham, B.J., Minamishima, Y., Dreesman, G.R., Haines, H.G. \& BeNYESH-MELNICK, M. (1971) Complementrequiring neutralising antibodies in hyperimmune sera to human cytomegaloviruses. Journal of Immunology, 107, 1618.

Haines, H.G., von EsSen, R. \& Benyesh-Melnick, M. (1971) Preparation of specific antisera to cytomegaloviruses in goats. Proceedings of the Society for Experimental Biology and Medicine, 138, 846.

HanshaW, J.B., Scheiner, A.P., Moxley, A.W., Gaev, L., ABEL, V. \& SCHEINER, B. (1976) School failure and deafness after 'silent' congenital cytomegalovirus infection. New England Journal of Medicine, 295, 468.

Henle, W., Henle, G., Scriba, M., Joyner, C.R., Harrison, F.S., von Essen, R., Paloheimo, J. \& Klemola, E. (1970) Antibody responses to the Epstein-Barr virus and cytomegaloviruses after open-heart and other surgery. New England Journal of Medicine, 282, 1068.

Ho, M., Suwansirikul, S., Dowling, J.N., Youngblood, L.A. \& ARMSTRONG, J.A. (1975) The transplanted kidney as a source of cytomegalovirus infection. New England Journal of Medicine, 293, 1109.

Just, M., Buergin-WolfF, A., Emoedi, G. \& Hernandez, R. (1975) Immunisation trials with live, attenuated cytomegalovirus (Towne 125). Infection, 3, 111.

LeVinsohn, E.M., Foy, H.M., KenNy, G.E., Wentworth, B.B. \& GrAYSTON, J.T. (1969) Isolation of cytomegalovirus from a cohort of 100 infants throughout the first year of life. Proceedings of the Society for Experimental Biology and Medicine, 132, 957.

Luthardt, Th., Siebert, H., Lösel, I., Quevedo, M. \& TODT, R. (1971) Cytomeglievirus-Infektionen bei Kindern mit Blutaustauschtransfusion im Neugeborenenalter. Klinische Wochenschrift, 49, 81.

MEDEARIS, D.N. (1964) Observations concerning human cytomegalovirus infection and disease. Johns Hopkins Hospital Bulletin, 114, 181

Medical Research Council Working Party on PostTranfusion Hepatitis (1974) Post-transfusion hepatitis in a London hospital: results of a two-year prospective study. Journal of Hygiene. Cambridge, 73, 173.

Monif, G.R.G., Egan, E.A., Held, B. \& Eitzman, D.V. (1972) The correlation of maternal cytomegalovirus infection during varying stages in gestation with neonatal involvement. Journal of Pediatrics, 80, 17.
Montgomery, R., Youngblood, L. \& Medearis, D.N. (1972) Recovery of cytomegalovirus from the cervix in pregnancy. Pediatrics, 49, 524.

Numazaki, Y., Yano, N., Morizuka, T., Takai, S. \& IsHIDA, N. (1970) Primary infection with human cytomegalovirus: virus isolation from healthy infants and pregnant women. American Journal of Epidemiology, 91, 410.

Olding, L.B., Jensen, F.C. \& Oldstone, M.B.A. (1975) Pathogenesis of cytomegalovirus infection. I. Activation of virus from bone marrow-derived lymphocytes by an in vitro allogenic reaction. Journal of Experimental Medicine, 141, 561.

Olson, L.C., Ketusinha, R., Mansuwan, P. \& Snitbhan, R. (1970) Respiratory tract excretion of cytomegalovirus in Thai children. Journal of Pediatrics, 77, 499.

Paloheimo, J.A., von Essen, R., Klemola, E., KäÄriäinen, L. \& Siltanen, P. (1968) Subclinical cytomegalovirus infections and cytomegalovirus mononucleosis after open heart surgery. American Journal of Cardiology, 22, 624.

Perham, T.G.M., Caul, E.O., Conway, P.J. \& Motr, M.G. (1971) Cytomegalovirus infection in blood donors: a prospective study. British Journal of Haematology, 20, 307.

Reynolds, D.W., Stagno, S., Hosty, T.S., Tiller, M. \& Alford, C.A. (1973) Maternal cytomegalovirus excretion and perinatal infection. New England Journal of Medicine, 289, 1.

Reynolds, D.W., Stagno, S., Stubis, K.G., Stahle, A.J., Livingston, M.M., SAXon, S.S. \& Alford, C.A. (1974) Inapparent cytomegalovirus infection with elevated cord IgM levels. New England Journal of Medicine, 290, 291.

Schaffer, P.A., FALK, L.A. \& Deinhardt, F. (1975) Attenuation of herpesvirus saimiri for marmosets after successive passage in cell culture at $39^{\circ} \mathrm{C}$. Journal of the National Cancer Institute, 55, 1243.

SHIELDS, R. (1976) Transformation and tumorigenicity. Nature. London, 262, 348.

Simpson, R.W. \& IINUMA, M. (1975) Recovery of infectious proviral DNA from mammalian cells infected with respiratory syncytial virus. Proceedings of the National Academy of Sciences of the United States of America, 72, 3230.

SPENCER, E.S. (1974) Clinical aspects of cytomegalovirus infection in kidney-graft recipients. Scandinavian Journal of Infectious Diseases, 6, 315.

Stagno, S., Reynolds, D.W., Lakeman, A., Charamella, L.J. \& Alford, C.A. (1973) Congenital cytomegalovirus infection: consecutive occurrence due to viruses with similar antigenic compositions. Pediatrics, 52, 788.

Stagno, S., Reynolds, D., Tsiantos, A., Fuccillo, D.A., Smith, R., Tiller, M. \& Alford, C.A. (1975) Cervical cytomegalovirus excretion in pregnant and nonpregnant women: suppression in early gestation. Journal of Infectious Diseases, 131, 522.

Stern, H. \& Tucker, S.M. (1973) Prospective study of cytomegalovirus infection in pregnancy. British Medical Journal, 2, 268.

Stevens, D.P., Barker, L.F., Ketcham, A.S. \& Meyer, H.M. (1970) Asymptomatic cytomegalovirus infection following blood transfusion in tumor surgery. Journal of the American Medical Association, 211, 1341.

YEAGER, A.S. (1974) Transfusion-acquired cytomegalovirus infection in newborn infants. American Journal of Diseases of Children, 128, 478.

ZHDANOV, V.M. (1975) Integration of viral genomes. Nature. London, 256, 471. 